\title{
Chemical composition of old world bluestem grasses as affected by cultivar and maturity
}

\author{
S.M. DABO, C.M. TALIAFERRO, S.W. COLEMAN, F.P. HORN, AND P.L. CLAYPOOL
}

\section{Abstract}

Old world bluestem (OWB) grasses (Bothriochloa spp.) have been used for herbage in the southern Great Plains for over 60 years, but release of new, well-adapted cultivars has led to a dramatic increase in use of these grasses in Oklahoma and adjacent areas during the last 15 years. Little information is avallable on the chemical composition of 0 WB grasses. The purpose of this study was to obtain information on the chemical composition of OWB grasses as affected by cultivar and maturation. Forage samples for chemical analyses were obtained from a 2-year field experiment conducted on a Kirkland silt loam soil (Udertic Paleustoll). Ten harvest dates (1-week interval between harvests) and 3 plant parts (whole plant, leaf, and stem) were imposed by split-split plot arrangement on established stands of 'Caucasian', 'Ganada', 'Plains', and 'WW-Spar' bluestem. Responses of variables were neutral detergent nber (NDF), acid detergent fiber (ADF), acid detergent lignin (ADL), and crude protein (CP). Concentrations of NDF, ADF, and ADL increased in whole plant and stem samples during the 10-week sumplins periods of both years. Qundratic equations best described changes in ADF during both years and in NDF and ADL in 1983, whereas linear equations best fitted changes in NDF and ADL in 1982. Concentration of NDF in leaves changed very little with maturation, but its change in whole plant and stems paralleled that described for ADF and ADL. Concentrations of CP decreased in all plant parts through harvest date elght (11-week old growth), with the changes beat described by quadratic equations. Changes in all constituents were less affected by advancins maturity in leaves than in stems. Maturity had a much greater efiect on concentration of all the chemical constituents than did cultivar. Initial concentrations of NDF in all plant parts exceeded the level (ca $600 \mathrm{~g} / \mathrm{F}^{-1}$ ) at which intake would likely be affected. Concentrations of CP also declined to levels by the 5th to 6th harveat dates, particularly in whole plant and stem parts, insufincient to supply dally requirements for most classes of mature beef cattle. The results point to the need to maintain and utilize these grasses to the extent posable in a juvenile, actively growing state to provide nutrition for growing livestock.

Key Words: Bothriochloa spp., NDF, ADF, ADL, CP, leaf, stem, whole plant

The old world bluestem (OWB) grasses (Bothriochloa spp.) comprise a highly heterogeneous group containing forms welladapted to the southern Great Plains. The desirable characteristics possessed by well-adapted types include good production potential, responsiveness to management, aggressive establishment and spread via seed, high palatability and satisfactory forage quality, and perhaps most importantly, tolerance to stress brought on either by overgrazing, climatic conditions, or both (Celarier and Harlan 1955, Eck and Sims 1984, Svejcar and Christiansen 1987). The OWB grasses are frequently planted on marginal crop land and used to complement and supplement native range production systems. Although OWB grasses have been used to some extent in the southern Great Plains for 60 years or more, the release of new, well-adapted cultivars has resulted in a dramatic increase in their use during the last 15 years. There is little information available on

Senior, second, and fifth authors are former research assistant, Dept. of Agronomy, and professors, Dept. of Agronomy and Statistics, respectively, Oklahoma State University, Stiliwater 74078. Third and fourth authors are research animal scientista, Livestock and Forage Research Laboratory, USDA-ARS, El Reno, Okla. 73036.

Manuscript accepted 3 September 1987, OAES no. 5333. the chemical composition of OWB grasses per se, or the comparative chemical composition of available cultivars.

Recently we reported the results of a study of the effects of maturation on dry matter yield, in vitro dry matter digestibility, and in vitro digestible dry matter yield of whole plant, leaves, and stems of 4 OWB cultivars (Dabo et al. 1987). The objective of this study was to characterize the chemical composition of whole plant and plant part samples as related to cultivar and maturity.

\section{Materials and Methods}

The study was conducted in 1982-83 on a Kirkland silt loam soil (Udertic Paleustoll) at the Agronomy Research Station, Stillwater, Okla. The field plot design was a split-split plot, in a randomized complete block with 4 replications. The cultivars used were: 'Caucasian' [Bothriochloa Caucasica (Trin.) C.E. Hubbard], 'Ganada' [B. ischaemum (L.) Keng var. ischaemum], 'Plains' [B. ischaemum (L.) Keng. var. ischaemum] and 'WW-Spar' [B. ischaemum (L.) Keng. var. ischaemum]. The $6 \times .6-\mathrm{m}$ plots were comprised of 5 rows spaced $15 \mathrm{~cm}$ apart. The test was seeded $28 \mathrm{July} 1980$. The nursery was staged by cutting all plots to a uniform height of $1.0 \mathrm{~cm}$ on 22 June 1982 and 25 May 1983. Plots were uniformly fertilized $\left(\mathrm{NH}_{4} \mathrm{NO}_{3}\right.$ ) at the rate of $120 \mathrm{~kg} \mathrm{~N} / \mathrm{ha}$ immediately after staging and then divided into ten $0.5-\mathrm{m}^{2}$ subplots. Abundant soil moisture was maintained via irrigation throughout the regrowth and sampling period each year. Prior to harvest, spacings between plots were cleared to eliminate border effects. Harvesting commenced 3 weeks from staging and continued at weekly intervals for 10 weeks. Harvest dates ( 1 through 10 ) were randomly assigned to subplots. At a given date, the entire subplot was harvested by clipping plants within subplots at a height of $1.3 \mathrm{~cm}$. The total green weight was recorded for yield measurements and 2 random grab samples were taken. One sample was oven dried at $65^{\circ} \mathrm{C}$ for 7 days to provide information on moisture content and to subsequently serve as a "whole plant" sample for laboratory analysis. The second sample was frozen and later separated into leaf, stem, and head (inflorescence) components. Leaves consisted of blades broken at the sheath. After separation, the respective plant parts were dried in a forced draft oven at $65^{\circ} \mathrm{C}$ for 7 days. Dry matter weights of leaves and stems were used to calculate leaf to stem ratios. Inflorescences were not processed further. Prior to laboratory analysis, dried samples were ground through a $5-\mathrm{mm}$ screen in a Wiley mill and then through a $1-\mathrm{mm}$ screen in a UDY Cyclone mill. This resulted in 20 to $30 \mathrm{~g}$ of ground forage which was used to determine forage chemical composition.

Chemical components [neutral detergent fiber (NDF), acid detergent fiber (ADF), acid detergent lignin (ADL), and crude protein (CP)] were measured by near infrared reflectance (NIRR) spectroscopy using a monochromator after calibration with chemical composition data from conventional laboratory analyses. Each sample was scanned 64 times with monochromatic light in the near infrared region, from 1,100 to $2,500 \mathrm{~nm}$. These scans were averaged and stored on a Digital Equipment Corporation minicomputer PDP 11/23. Seven hundred data points at $2.0 \mathrm{~nm}$ intervals were recorded for each sample. One-half of the samples were analyzed conventionally for NDF and CP. One-fourth of the samples were analyzed for ADF and ADL. Samples were selected for conventional analyses as follows: 2 replications were first selected, providing 240 samples each year for NDF and CP; samples for 
ADF and ADL were obtained by random selection of 1 of these 2 reps. The CP measurements were made in duplication from Kjeldahl N $\times 6.25$ (AOAC 1975), and the various fibers were determined using the procedures outlined by Van Soest $(1967,1973)$. Calibration of the monochromator was achieved using the computer software developed at Pennsylvania State University (Shenk et al. 1977). The software combined NIR reflectance data with the laboratory analysis, performed the necessary mathematical transformations $(\log 1 / R$, 1st and 2 nd derivatives), and used a modified stepwise linear regression procedure to find the wavelengths most useful for predicting the desired quality parameter. Seven calibration equations resulted and included 1 to 7 wavelengths and their regression coefficients for predicting forage quality characters. On the basis of the R-square, bias, and standard error of prediction statistics, an equation was chosen to predict the chemical composition from the reflectance spectra of all samples.

An overall statistical analysis was first conducted on each response variable using the ANOVA procedures for a split-split plot arrangement (Steel and Torrie 1960). Cultivars were main plots; harvest dates and plant parts (leaf, stem, and whole plant) were sub and sub-sub plots, respectively. Subsequently the chemical data were analyzed by year and plant part in order to assess cultivar differences and effects of maturation. Orthogonal polynomials were used to partition the sampling date sum-of-squares into linear, quadratic, and deviation from quadratic components. Regression analysis was used to describe the response of cultivars and plant parts within cultivars to harvest date. The rates of change of response variables across harvest dates were obtained by taking the first derivatives of prediction equations. A significance level of .05 was used throughout. Maximum and minimum air tempera-

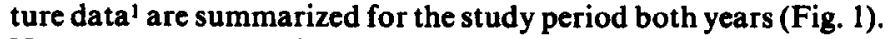
No attempt was made to relate the week-to-week variations to specific chemical parameters.

\section{Results}

Mean weekly minimum and maximum temperatures for the 13 weekly periods (staging to week of final harvest) differed between years (Fig. 1). Temperatures in 1982 tended to be higher than those in 1983 until about 9 weeks post staging, at which time the reverse was true. The experiment in 1982 was initiated about 4 weeks later than in 1983, which accounted for the higher temperatures. Because most of the 1st, 2nd, and 3rd order interactions between treatment variables were significant, data for each response variable are presented by year, plant part, and cultivar.

\section{Neutral Detergent Fiber}

Initial NDF concentrations were $700 \pm 50 \mathrm{~g} \mathrm{~kg}^{-1}$ and increased in whole plant and stem parts, but changed very little in leaves, during the 10-week sampling period of both years (Fig. 2). Initial concentrations in whole plant and stem samples were slightly higher in 1982 than in 1983. In 1982, the increases in whole plant and stem NDF concentration that resulted during maturation were smaller compared to 1983 , and were adequately explained by linear equations (Table 1). In 1983, changes in NDF concentration in these plant parts were best explained by quadratic equations, with substantive increases occurring through harvest week 10 . The rate and extent of increase in NDF concentration was greatest in stems during each of the 2 years. Overall, NDF concentration in stems was about $100 \mathrm{~g} \mathrm{~kg}^{-1}$ greater than in leaves.

Although differences in NDF among cultivars were statistically significant $(P<.05)$, they were generally of small magnitude and not consistent over harvest dates, plant parts, or years, and no strong trends were apparent. Ganada and WW-Spar had slightly higher and lower NDF concentrations, respectively, than the other cultivars in whole plant and stem samples. There was also some tendency for NDF concentration in leaves to be slightly higher in Plains and lower in Caucasian than in other cultivars.

\footnotetext{
IClimatological data Oklahoma. V. 91-92.
}

\section{Acid Detergent Fiber}

Concentrations of ADF were strongly affected by maturation in whole plant, stem, and leaf samples (Fig. 3). Initial ADF concentrations were similar in whole plant and leaf samples, which were lower than those in stems. Also, initial concentrations were slightly higher in 1982 compared to 1983. Changes in ADF concentrations in all plant parts with increasing maturity were best explained by quadratic equations (Table 1). ADF concentration in whole plant and stem parts generally increased through harvest date 8, with the rates of increase being somewhat greater in 1983 than in 1982, particularly during the first half of the 10-week sampling period. Both the rate and extent of change in ADF concentration of leaves was considerably less than in whole plant and stem parts. When averaged over cultivars, harvest dates, and years, leaves contained 52 and $95 \mathrm{~g} \mathrm{~kg}^{-1}$ less ADF than whole plant and stems, respectively.

Cultivar differences in ADF were statistically significant $(P<.05)$, but generally of small magnitude similar to those for NDF. Caucasian and Plains had higher ADF concentrations in all plant parts than did Ganada and WW-Spar. Also, rates of increase in ADF concentrations during early harvests were somewhat greater in whole plant and stem parts of Plains and Caucasian compared to Ganada and WW-Spar, which is reflected in significant $(P<.05)$ cultivar $X$ harvest data interactions.

\section{Acid Detergent Lignin}

Concentration of ADL was strongly affected by plant maturation, more so in whole plant and stems than in leaves (Fig. 4). Initial concentrations in whole plant and leaves were slightly higher in 1982 than in 1983. In 1982, ADL concentrations increased throughout the 10-week sampling period, with the changes being adequately explained by linear equations (Table 1). In 1983, changes occurring due to maturation were best described by quadratic equations and revealed substantial increases in ADL concentrations in whole plant and stems through harvest date 7 before leveling off. Rate and extent of increases in ADL concentration in leaves were substantially less than in whole plant and stem parts. When averaged over cultivars, harvest dates, and years, mean ADL concentrations for leaf, whole plant, and stem parts were, respectively, 45,56 , and $67 \mathrm{~g} \mathrm{~kg}^{-1}$.

Differences in ADL concentrations due to cultivars were significant $(P<.05)$, both years, but the magnitude of the differences were much greater in 1982 than in 1983. The largest differences occurred in whole plant and stem parts in 1982 during the latter half of the sampling period. Initial concentrations of ADL in the cultivars were not greatly different, but the rate and extent of increase was generally greater for Caucasian and Plains than for the Ganada and WW-Spar, particularly in whole plant and stem parts. Ganada had a lower rate of ADL increase through the samplng period than any of the other cultivars. When averaged over plant parts, harvest dates, and years, Caucasian, Plains, WW-Spar, and Ganada had respective mean $A D L$ concentrations of $58,58,55$, and $53 \mathrm{~g} \mathrm{~kg}^{-1}$.

\section{Crude Protein}

Crude protein concentration was also strongly influenced by plant maturation $(P<.05)$ in all plant parts in both years (Fig. 5). Changes in CP through the sampling periods of both years were best described by quadratic equations (Table 1 ). The changes were characterized by rapid decline in all plant parts through the seventh to eighth harvest date, and little change during the last 2 weeks. Initial CP concentrations were highest in leaves and lowest in stems. The extent of decline was greatest in stems and least in leaves. When averaged over cultivars, harvest dates, and years, mean CP concentrations for leaf, whole plant, and stem samples were 95,71 , and $47 \mathrm{~g} \mathrm{~kg}^{-1}$, respectively.

Caucasian had consistently lower CP concentrations in all plant parts compared to the other cultivars. The cultivar $X$ harvest date interaction was significant only in 1982 for stems due to a more rapid rate of decline of Caucasian compared to the other cultivars. 

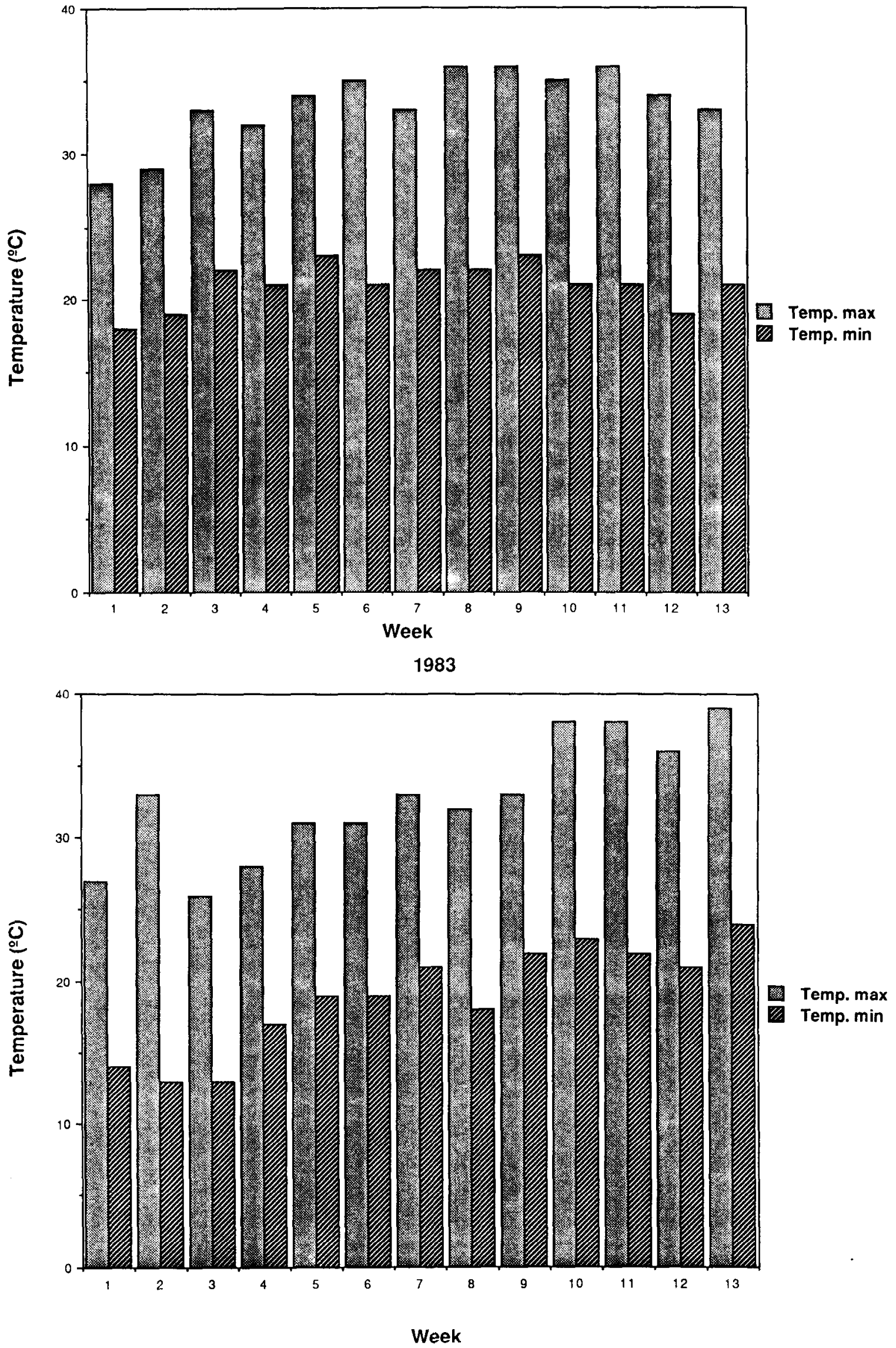

Fig. 1. Weekly temperature $\left({ }^{C}\right.$ ) for 1982 and 1983 study periods. 

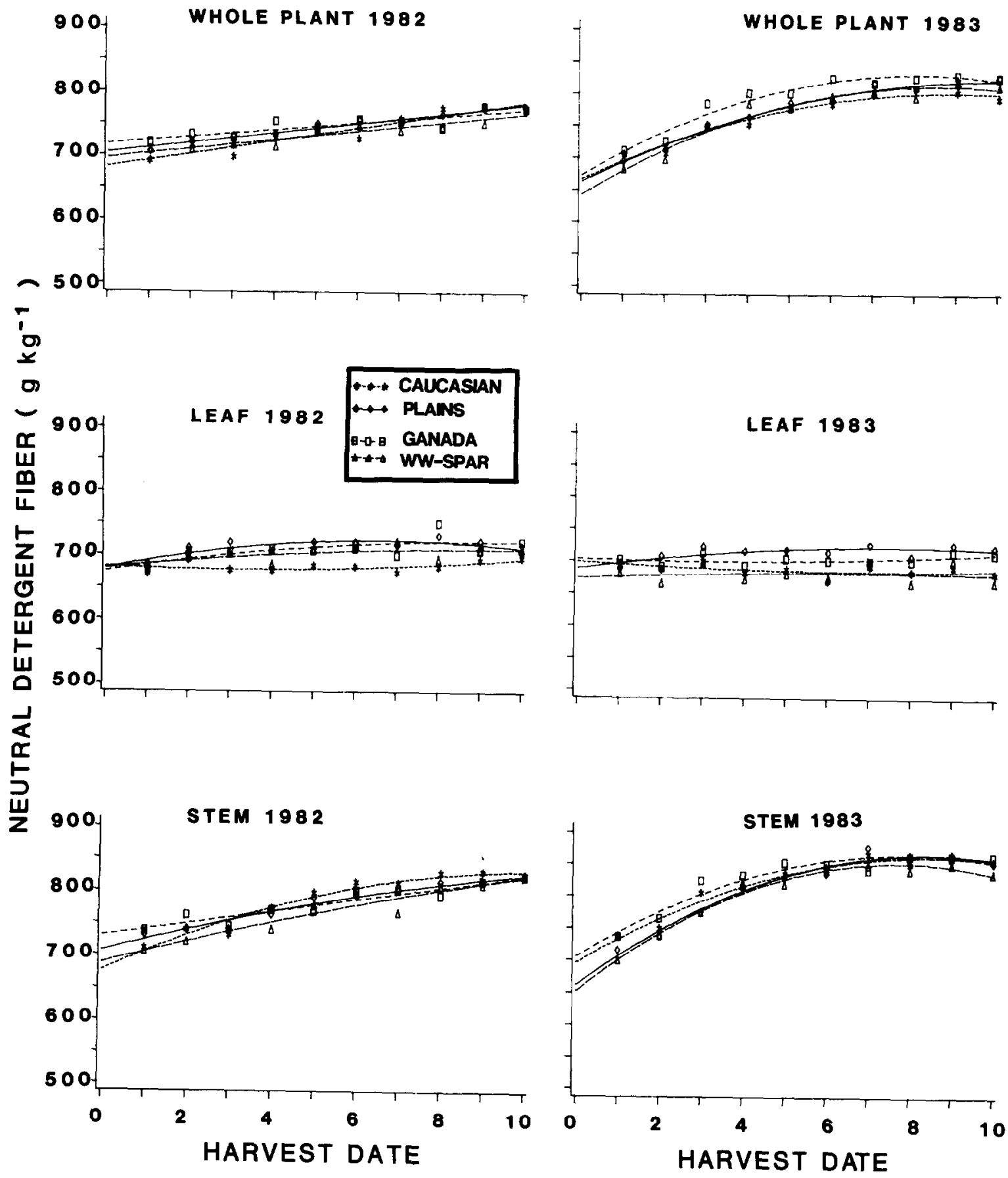

Fig. 2. Neutral detergent fiber (NDF) of whole plants, leaves, and stems of 4 old world bluestem cultivars at 10 harvest dates. JOURNAL OF RANGE MANAGEMENT 41(1), January 1988 

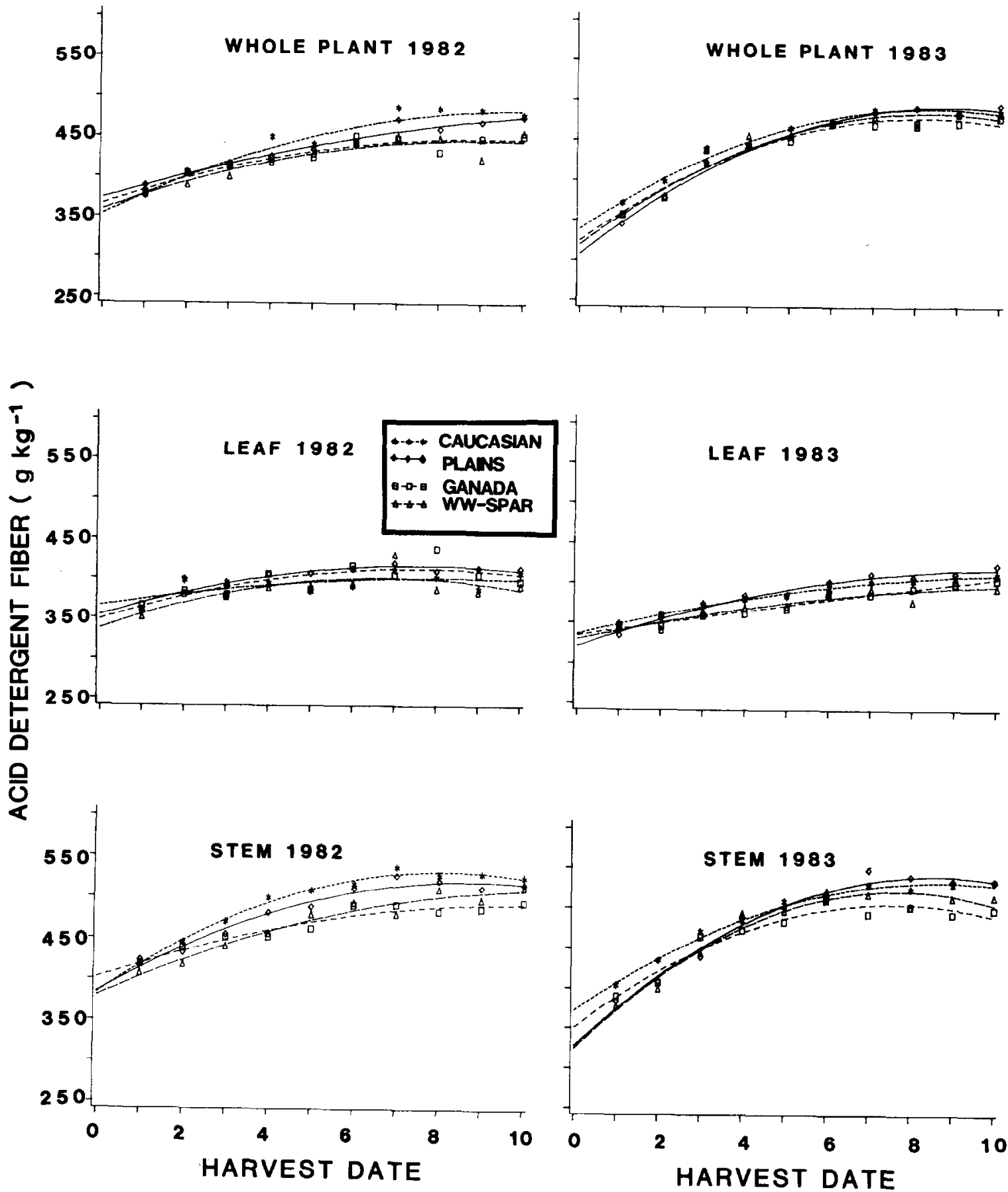

Fit. 3. Acid detergent fiber (ADF) of whole plants, leaves, and stems of 4 old world bluestem cultivars at 10 harvest dates. 

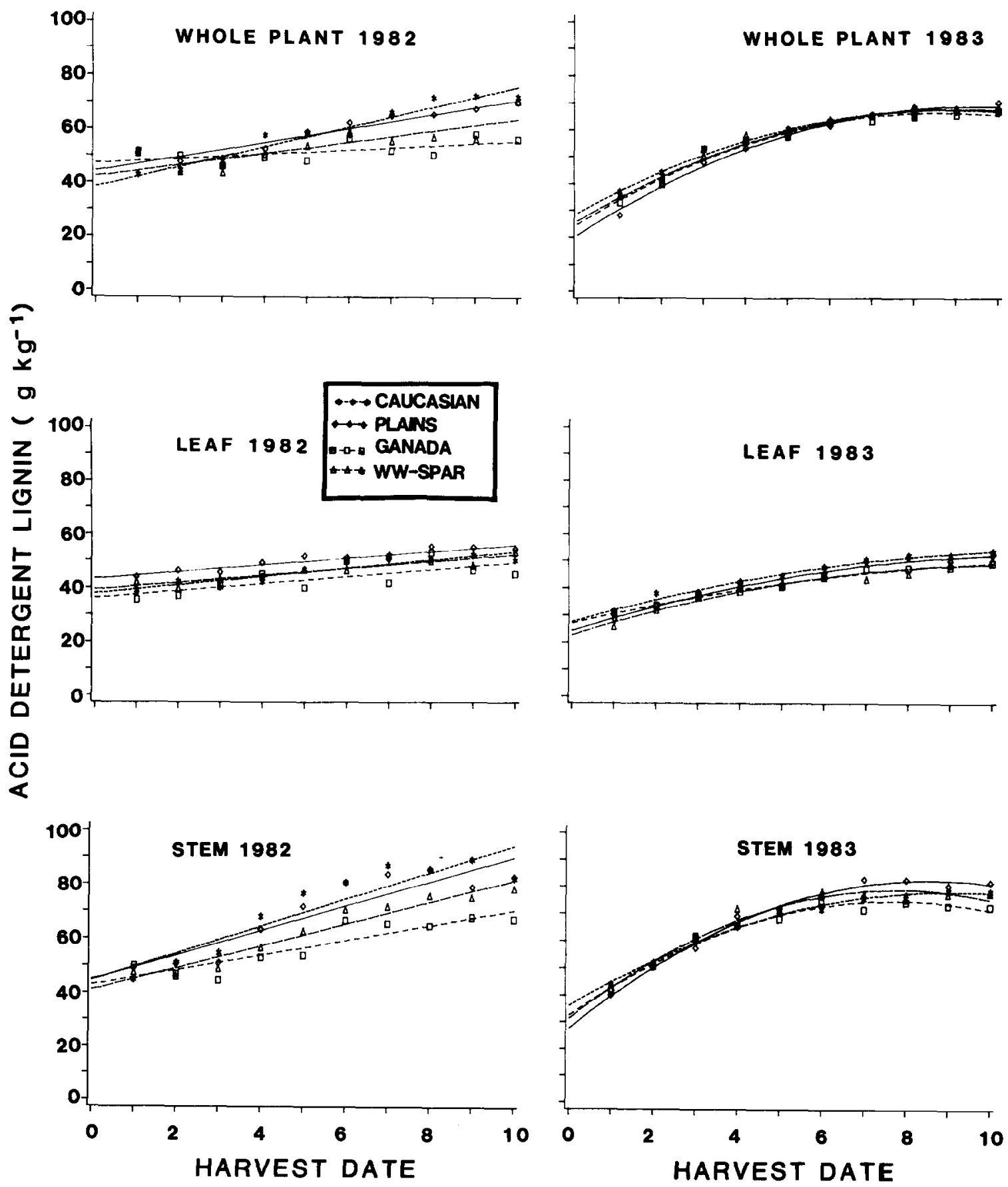

Fig. 4. Acid detergent lignin (ADL) of whole plants, leaves, and stems of 4 old world bluestem cultivars at 10 harvest dates. 

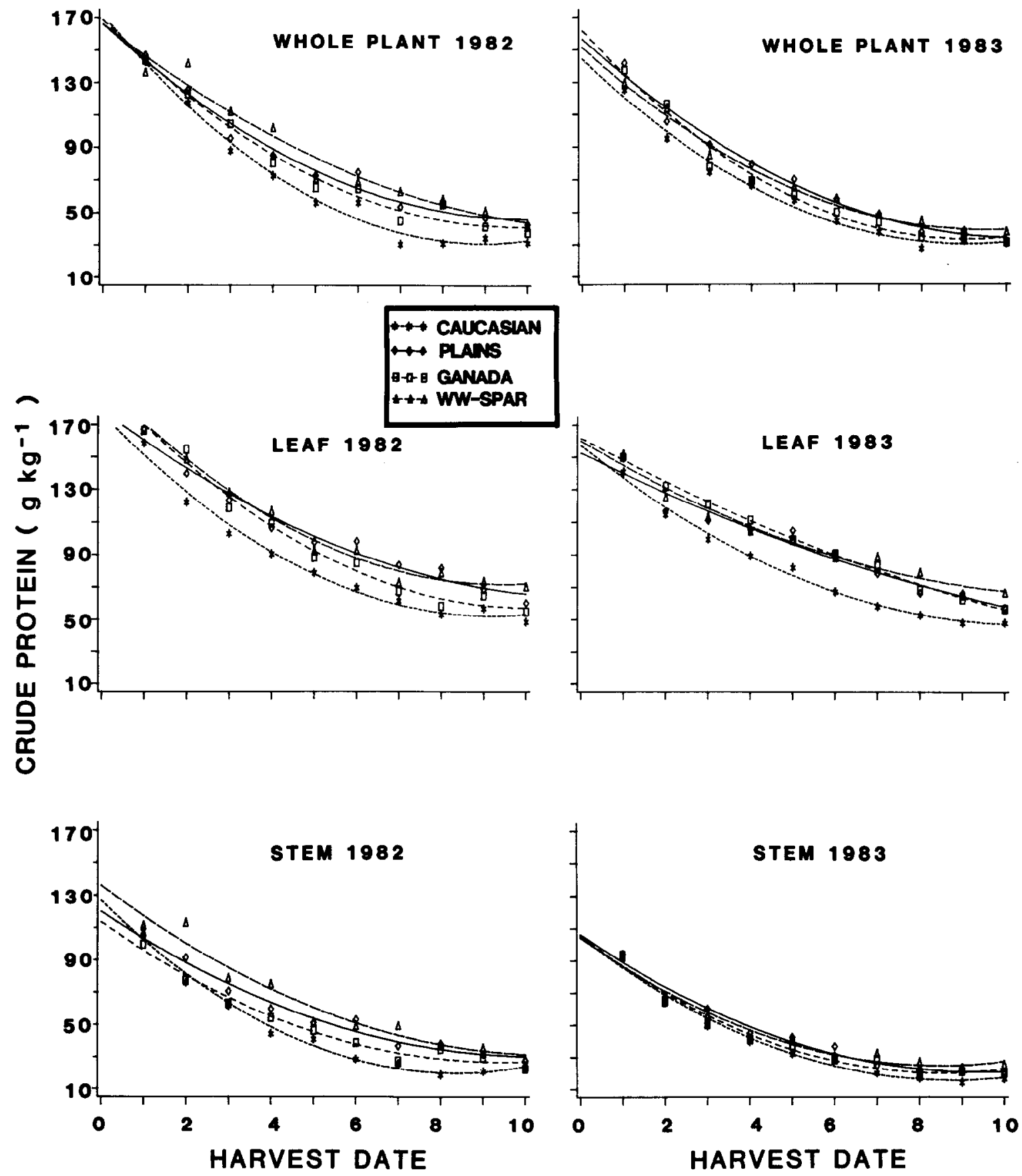

Fig. 5. Crude protein (CP) of whole plants, leaves, and stems of 4 old world bluestem cultivars at 10 harvest dates. 
Table 1. Regreasion of chemical components on harveat date in old world blueatem cultivars.'

\begin{tabular}{|c|c|c|c|c|c|c|c|c|c|c|c|c|c|c|c|c|}
\hline \multirow[b]{2}{*}{ Cultivar } & \multicolumn{6}{|c|}{ Whole Plants } & \multicolumn{5}{|c|}{ Leaves } & \multicolumn{5}{|c|}{ Stems } \\
\hline & YR & bo & $b_{1}$ & $b_{2}$ & $R^{2}$ & SE & bo & $b_{1}$ & $\mathbf{b}_{2}$ & $R^{2}$ & SE & bo & $b_{1}$ & $b_{2}$ & $R^{2}$ & SE \\
\hline & \multicolumn{16}{|c|}{ NDF $g_{\text { kg }}{ }^{-1}$} \\
\hline \multirow[t]{2}{*}{ Caucasian } & 82 & 683 & +10.2 & & .72 & 19 & 682 & $-2.6^{\circ}$ & +0.4 & .24 & 11 & 676 & +30.6 & -1.5 & .88 & 16 \\
\hline & 83 & 667 & +30.5 & -1.7 & .78 & 20 & 698 & -3.9 & +0.3 & .05 & 14 & 696 & +39.2 & -2.3 & .88 & 17 \\
\hline \multirow[t]{2}{*}{ Ganada } & 82 & 718 & +5.6 & & .43 & 19 & 675 & +10.4 & -0.6 & .29 & 20 & 730 & +9.8 & -0.1 & .72 & 17 \\
\hline & 83 & 673 & +39.3 & -2.5 & .80 & 21 & 703 & -1.6 & +0.3 & .13 & 12 & 705 & +40.4 & -2.6 & .78 & 22 \\
\hline \multirow[t]{2}{*}{ Plains } & 82 & 705 & +7.7 & & .84 & 10 & 679 & +13.3 & -1.0 & .37 & 13 & 706 & +17.6 & -0.6 & .86 & 14 \\
\hline & 83 & 663 & +32.1 & -1.6 & .88 & 17 & 689 & +9.2 & -0.6 & .22 & 16 & 661 & +48.5 & -2.9 & .88 & 20 \\
\hline \multirow[t]{2}{*}{ WW-SPAR } & 82 & 697 & +7.0 & & .67 & 15 & 680 & +6.8 & -0.4 & .11 & 24 & 687 & +17.6 & -0.4 & .77 & 22 \\
\hline & 83 & 643 & +39.7 & -2.3 & .84 & 20 & 674 & +2.9 & -0.2 & .10 & 18 & 652 & +51.9 & -3.4 & .85 & 21 \\
\hline \multicolumn{17}{|c|}{ 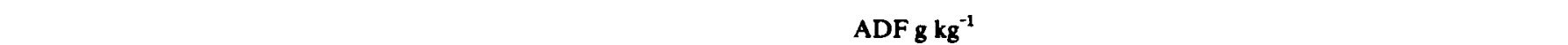 } \\
\hline \multirow[t]{2}{*}{ Caucasian } & 82 & 353 & +25.9 & -1.3 & .80 & 18 & 365 & $+8.7^{\circ}$ & -0.5 & .30 & 14 & 383 & +36.7 & -2.3 & .91 & 12 \\
\hline & 83 & 339 & +36.1 & -2.2 & .84 & 17 & 336 & +13.2 & -0.6 & .93 & 6 & 371 & +37.1 & -2.1 & .80 & 22 \\
\hline \multirow[t]{2}{*}{ Ganada } & 82 & 366 & +18.4 & -1.0 & .58 & 19 & 348 & +17.1 & -1.1 & .41 & 20 & 401 & +18.5 & -0.9 & .75 & 15 \\
\hline & 83 & 325 & +37.6 & -2.3 & .86 & 16 & 335 & +7.9 & -0.1 & .85 & 9 & 350 & +40.8 & -2.7 & .79 & 20 \\
\hline \multirow[t]{2}{*}{ Plains } & 82 & 373 & +16.1 & -0.6 & .80 & 14 & 353 & +16.7 & -0.1 & .47 & 17 & 384 & +31.1 & -1.8 & .85 & 16 \\
\hline & 83 & 308 & +42.0 & -2.4 & .93 & 14 & 321 & +18.7 & -0.9 & .88 & 10 & 328 & +49.7 & -2.9 & .95 & 13 \\
\hline \multirow[t]{2}{*}{ WW-SPAR } & 82 & 359 & +19.5 & -1.1 & .65 & 17 & 337 & +19.9 & -1.4 & .27 & 24 & 379 & +24.3 & -1.1 & .76 & 21 \\
\hline & 83 & 320 & +39.6 & -2.4 & .91 & 13 & 330 & -11.6 & -0.5 & .80 & 10 & 324 & +51.2 & -3.3 & .90 & 16 \\
\hline \multicolumn{17}{|c|}{ ADL $\mathrm{g} \mathrm{kg}^{-1}$} \\
\hline \multirow[t]{2}{*}{ Caucasian } & 82 & 38 & +3.7 & & .82 & 5 & 38 & +1.5 & & .48 & 4 & 45 & +5.0 & & .78 & 8 \\
\hline & 83 & 29 & +8.8 & -0.5 & .91 & 3 & 28 & +4.5 & -0.2 & .86 & 3 & 36 & +9.3 & -0.5 & .95 & 3 \\
\hline \multirow[t]{2}{*}{ Ganada } & 82 & 47 & +0.8 & & .18 & 5 & 36 & +1.3 & & .26 & 6 & 43 & +2.8 & & .66 & 6 \\
\hline & 83 & 25 & +9.8 & -0.6 & .92 & 3 & 27 & +3.7 & -0.1 & .78 & 3 & 32 & +11.0 & -0.8 & .88 & 4 \\
\hline \multirow{2}{*}{ Plains } & 82 & 45 & +2.6 & & .52 & 8 & 43 & +1.2 & & .48 & 4 & 45 & +4.5 & & .66 & 10 \\
\hline & 83 & 21 & +10.3 & -0.5 & .95 & 3 & 24 & +5.0 & -0.2 & .84 & 4 & 26 & +12.8 & -0.7 & .97 & 3 \\
\hline \multirow{2}{*}{ WW-SPAR } & 82 & 42 & +2.1 & & .40 & 8 & 39 & +1.3 & & .25 & 7 & 41 & +4.1 & & .71 & 8 \\
\hline & 83 & 26 & +9.4 & -0.5 & .92 & 3 & 23 & +5.0 & -0.2 & .74 & 5 & 31 & +12.2 & -0.8 & .93 & 4 \\
\hline \multicolumn{17}{|c|}{$\mathrm{CP} \mathrm{g} \mathrm{kg}^{-1}$} \\
\hline \multirow[t]{2}{*}{ Caucasian } & 82 & 172 & -31.7 & +1.8 & .95 & 8 & 177 & -27.3 & +1.5 & .94 & 9 & 127 & -25.8 & +1.6 & .95 & 7 \\
\hline & 83 & 144 & -25.3 & +1.4 & .92 & 9 & 157 & -21.1 & +1.0 & .95 & 7 & 105 & -20.4 & +1.2 & .94 & 6 \\
\hline \multirow[t]{2}{*}{ Ganada } & 82 & 169 & -26.3 & +1.4 & .90 & 12 & 196 & -27.7 & +1.4 & .91 & 12 & 114 & -18.7 & +1.0 & .92 & 7 \\
\hline & 83 & 162 & -28.6 & +1.6 & .95 & 8 & 162 & -14.1 & +0.4 & .93 & 9 & 105 & -20.1 & +1.2 & .94 & 6 \\
\hline Plains & 82 & 166 & -24.3 & +1.2 & .79 & 17 & 180 & -19.8 & +0.9 & .74 & 19 & 120 & -17.5 & +0.9 & .80 & 13 \\
\hline & 83 & 157 & -23.7 & +1.1 & .92 & 10 & 153 & -13.0 & +0.4 & .75 & 16 & 106 & -18.2 & +1.0 & .89 & 8 \\
\hline WW-SPAR & 82 & 166 & -20.8 & +0.9 & .75 & 20 & 196 & -26.6 & +1.4 & .70 & 23 & 136 & -19.8 & +0.9 & .74 & 17 \\
\hline & 83 & 151 & -23.8 & +1.3 & .86 & 12 & 160 & -15.8 & +0.7 & .68 & 18 & 104 & -18.9 & +1.1 & .85 & 9 \\
\hline
\end{tabular}

'bo is intercept, $b_{1}$ and $b_{2}$ are linear and quadratic slopes, $\boldsymbol{R}^{2}$ is the coefficient of determination and $\mathrm{SE}$ is the standard error estimate.

No consistent differences in CP content of Ganada, Plains, and WW-Spar across plant parts and years were evident.

\section{Discussion}

Stage of maturity had a much greater effect on the chemical composition of all plant parts than did cultivars. With the possible exception of ADL, differences in the chemical constituents between cultivars, although statistically significant, were not great. The considerable effect of environment on fiber composition of forages is exemplified by the differences obtained between years. Higher initial concentrations of NDF, ADF, and ADL in 1982 compared to 1983 , in all plant parts, likely resulted primarily from higher temperatures that prevailed during the regrowth period because of the later starting date. Rates of increase in fiber components also tended to be greater during the first half of the sampling period in 1982 compared to 1983 , while the cultivar differences tended to be greatest during the latter half of the 1982 period. Our results suggest that the greatest differences in fiber concentrations among cultivars likely occur during the summer months when higher temperatures prevail. Initial levels of, and changes in, leaf to stem ratios previously reported (Dabo et al. 1987) were similarly affected by year, i.e., initial ratios were higher, and the rate of decrease at early harvests greater, in 1982 compared to 1983 . These results, and those reported by Stuthman and Marten (1972) and Cherney and Marten (1982), suggest tht age of tissue at cutting may be less important for the measured chemical parameters than climatic conditions under which the forage is grown.

Concentrations of NDF measured in this experiment agree with previously reported estimates (Horn and Jackson 1979). The values reported herein exceeded $600 \mathrm{~g} \mathrm{~kg}^{-1}$, at about which point NDF may start limiting intake by animals (Griffin et al. 1980 and Van Soest 1965), in all plant parts even at the initial harvest date. Likewise, ADF and ADL values were relatively high, but typical of other warm-season perennial grasses. These values help explain cultivar differences in in vitro dry matter disappearance (IVDMD) previously reported (Dabo et al. 1987). The higher IVDMD of Ganada, compared to the other cultivars, may be explained by its greater hemicellulose and lower ADL concentrations, and slower decrease in leaf to stem ratios with maturity. The generally lower IVDMD concentrations of Caucasian, relative to the other cultivars, likewise are related to a higher indigestible fiber fraction and more rapid increases in leaf to stem ratio with maturation. Leaves contained less fiber and more CP than stems, and consequently are more digestible at all stages of development. However, the rate of decline in leaf to stem ratio and the contribution of the digestible fiber fraction (i.e., hemicellulose) within the individual cultivar are better indicators of quality than the leaf to stem ratio per se for these grasses. From this standpoint, Ganada is clearly superior to Caucasian, Plains, and WW-Spar. However, this must be balanced with total production of digestible dry matter, and generally the 
greatest increases in growth and consequent dry matter yield are achieved via relatively greater increases in the stem fraction of total plant growth. This relationship appears to hold for these OWB cultivars; consequently, while Ganada has significantly higher nutritive value than the other cultivars, its yield of dry matter and total digestive dry matter is lower (Dabo et al. 1987).

The rapid decline in CP content in leaves and particularly stems with maturation of these grasses indicates that minimal daily CP requirements of most classes of mature animals would not be met when the forage is 7 to 8 weeks of age or older. By this time the CP concentration of stems was generally below $70 \mathrm{~g} \mathrm{~kg}^{-1}$ and stems constituted a greater proportion of total plant mass than did leaves. Increases in fiber components and decreases in CP and leaf to stem ratio $(\mathrm{L} / \mathrm{S})$ with advancing maturity point to the need to utilize management techniques to the extent possible that will maintain OWB grasses in a juvenile actively growing state for best animal performance.

\section{Literature Cited}

AOAC methods. 1975. Official methods of analysis. Association of Official Analytical Chemists, Washington, D.C.

Celarler, R.P., and J.K. Harlan. 1955. Studies on old world bluestems, Oklahoma A\&M Coll. Agr. Exp. Sta. Tech. Bull. No. T-58.

Cherney, J.H., and G.C. Marten. 1982. Small grain crop forage potential: I. Biological and chemical determinants of quality, and yield. Crop Sci. 22:227-231.
Dabo, S.M., C.M. Tallaferro, S.W. Coleman, F.P. Horn, and P.L. Claypool. 1987. Yield and digestibility of old world bluestem grasses as affected by cultivar, plant part and maturity. J. Range Manage. 40:10-15.

Eck, H.V., and P.L. Sims. 1984. Grass species adaptability in the southern high plains-a 36-year assessment. J. Range Manage. 37:211-217.

Grifin, J.L., P.J. Wanganess, and G.A. Jung. 1980. Forage quality evaluation of 2 warm-season range grasses using laboratory and animal measurements. Agron. J. 72:951-956.

Horn, F.P., and W. Jackson. 1979. Digestibility of 5 "Old World Bluestem" hays. Oklahoma Agr. Exp. Sta. Anim. Sci. Res. Rep. MP-104

Shenk, J.S., K.H. Norris, R.F. Barnes, and G.W. Fissel. 1977. Forage and feestuff analysis with infrared reflectance spectro-computer system. Proc. 13th Int. Grass. Cong., Leipzip, G.D.R.

Steel, G.D.R., and J.H. Torrie. 1960. Principles and procedures of statistics. McGraw-Hill Books Co., Inc., New York.

Stuthman, D.D., and G.C. Marten. 1972. Genetic variation in yield and quality of oat forage. Crop Sci. 12:831-833.

Svejear, T., and S. Chriatiansen. 1987. Grazing effects on water relations of Caucasian bluestem. J. Range Manage. 40:15-18.

Van Soest, P.J. 1965. Symposium on factors influencing the voluntary intake of herbage by ruminants: Voluntary intake in relation to chemical composition and digestibility. J. Anim. Sci. 24:834-843.

Van Soest, P.J. 1967. Development of a comprehensive system of feed analyses and its application to forages. J. Anim. Sci. 26:119-128.

Van Soest, P.J. 1973. Feeds. Collaborative study of acid detergent fiber and lignin. J. AOAC 56:781-784. 